\title{
ANALISA PUBLIC FINANCE MANAGEMENT KABUPATEN MERAUKE
}

\author{
Ida Ayu Purba Riani ${ }^{2}$ \\ purbariani@gmail.com
}

\begin{abstract}
In the era of regional autonomy, managements in local governments set out accountability and transparency in managing the regional public finance including planning, budgeting, implementation, administering, reporting, accountable and controlling. As from writer's observation of development performance in Merauke regency, it revealed that there was inadequate development in reaching the ideal development performance although the management was generally wellmanaged. This paper applied Public Finance Management analysis technique to analyse primary data. The results showed the overall score was $52 \%$ from total statements which including 9 sectors. The highest scores were in the planning, cash management, procurement as well as accounting and reporting areas.
\end{abstract}

Key words: Public Finance, Management, Accountability.

\section{PENDAHULUAN}

Seiring dengan diterapkannya Undang-undang No. 32 Tahun 2004 tentang Otonomi Daerah dan Undang-undang No. 33 Tahun 2004 tentang Perimbangan Keuangan antara Pemerintah Pusat dan Pemerintah Daerah, terjadi pergeseran dan pengelolaan keuangan publik di Indonesia. Reformasi segala bidang mulai diberlakukan, yang meliputi reformasi kelembagaan dan reformasi manajemen sektor publik terutama yang berkaitan dengan pengelolaan keuangan daerah demi untuk mendukung terciptanya good governance.

Dalam penyelenggaraan pemerintah daerah di era otonomi daerah tersebut yang dimaksud dengan pengelolaan keuangan daerah mencakup keseluruhan kegiatan perencanaan, penganggaran,

\footnotetext{
${ }^{2}$ Staf Dosen Jurusan IImu Ekonomi Fakultas Ekonomi Dan Bisnis Universitas Cenderawasih
} 
pelaksanaan, penatausahaan, pelaporan, pertanggungjawaban, dan pengawasan. Dimana pola dan proses yang dilaksanakan dalam pengelolaan keuangan daerah mengacu pada paket reformasi keuangan negara, yang dituangkan dalam beberapa peraturan perundangundangan, seperti UU Nomor 17 Tahun 2003 tentang Keuangan Negara, UU Nomor 1 Tahun 2004 tentang Perbendaharaan Negara, UU Nomor 25 Tahun 2004 tentang Sistem Perencanaan Pembangunan Nasional, dan seterusnya.

Meskipun sudah di atur dalam undang-undang dan turunannya, namun proses dan pelaksanaan pengelolaan keuangan daerah tidaklah serta merta membawa kemanfaatan optimal bagi pembangunan daerah. Sebagai contoh di Kabupaten Merauke. Meskipun belanja daerah yang dikelolanya selama ini tercatat selalu menempati urutan pertama terbesar di wilayah Papua, seperti di tahun 2014 yang mencapai Rp. 1,71 triliun, dengan pendapatannya sebesar Rp. 1,82 triliun, namun kinerja pembangunan sosial ekonomi yang dihasilkan belum optimal, tidak sebanding dengan pendapatan daerah yang dimiliki dan belanja daerah yang dikeluarkan.

Di sektor kesehatan misalkan, Angka Harapan Hidup Kabupaten Merauke ternyata masih di bawah Kabupaten Yapen Waropen dan Biak Numfor. Angka Harapan Hidup Kabupaten Merauke sebesar 66,49 tahun. Sementara di Kabupaten Yapen Waropen dan Biak Numfor masingmasing bisa mencapai 68,63 tahun dan 67,85 tahun. Padahal kedua kabupaten ini mengelola pendapatan dan belanja daerah yang jauh lebih rendah dibandingkan Kabupaten Merauke. Demikian juga dengan sarana dan prasarana kesehatan yang tersedia terlihat belum ideal, walaupun anggaran kesehatannya cukup besar, dimana rata-rata rasio penduduk per dokter bisa mencapai 2.808 (idealnya 2.500 per dokter), kemudian untuk puskesmas rasionya sekitar 71.562 penduduk per puskesmas (idealnya 20.000 per puskesmas). 
Sedangkan kinerja pembangunan di sektor pendidikan tidak berbeda jauh kondisinya dengan sektor kesehatan. Rasio guru terhadap murid misalkan, untuk semua jenjang pendidikan tampak belum ideal. Rata-rata per tahun rasio guru-murid SD adalah 25 murid per guru, SMP sebesar 17 murid per guru, dan SMA/SMK sebesar 15 murid per guru Seluruh angka rasio ini masih di atas ideal, sehingga diperlukan penambahan guru pada semua jenjang pendidikan untuk mencapai rasio yang ideal. Selain itu akses masyarakat terhadap fasilitas pendidikan yang dibangun oleh pemerintah kabupaten selama ini dapat dikatakan kurang merata, yang diindikasikan dengan APM (Angka Partisipasi Murni) pada semua jenjang pendidikan masih dibawah $100 \%$.

Dalam pembangunan ekonomi juga kelihatan kurang maksimal berpihak pada kelompok masyarakat yang berpendapatan rendah yang lebih banyak berkecimpung dalam sektor pertanian. Tercatat pertumbuhan realisasi belanja sektor pertanian cenderung menurun. Oleh karena laju pertumbuhan penduduk meningkat, akhirnya berdampak pada menurunnya belanja perkapita di sektor pertanian. Fakta lainnya, perhatian pemerintah kabupaten terhadap pemberdayaan ekonomi masyarakat belum maksimal. Dan, walaupun tingkat kemiskinan Kabupaten Merauke adalah terendah di Papua, dan cenderung mengalami penurunan, namun ekonomi masyarakat asli Merauke masih rentan dan banyak yang hidup dalam kemiskinan.

Berbagai fenomena di atas menunjukan bahwa pengelolaan keuangan daerah di Kabupaten Merauke belum optimal dilaksanakan. Pemerintah daerah yang berperan sebagai agen pembangunan sepertinya tidak maksimal mengelola pendapatan dan belanja daerah yang dimiliki, dimana hal ini karena sangat dipengaruhi oleh kapasitas manajemen sumberdaya pembangunan termasuk keuangan dan asetaset daerah. Demikian juga halnya dengan pengawasan internal dan eksternal merupakn faktor determinasi yang sangat penting sebagai jaminan adanya akuntabilitas dari pengelolaan keuangan daerah. 
Sudah menjadi isu yang umum bahwa kinerja pembangunan daerah belum begitu optimal dihasilkan dalam masa otonomi daerah dan desentralisasi fiskal ini. Oleh karenanya Kapasitas Pengelolaan Keuangan Publik (Public Financial Management Capacity) di daerah sebagai salah satu aspek penting dalam optimalisasi manfaat pembangunan daerah perlu dievaluasi kinerjanya.

Bidang-bidang otonomi daerah dan desentralisasi fiskal di Indonesia dalam konteks studi Public Finance Management (PFM), paling tidak meliputi 9 (sembilan) bidang yaitu: 1) kerangka peraturan perundangan daerah; 2) perencanaan dan penganggaran; 3) pengelolaan kas; 4) pengadaan barang dan jasa; 5) akuntansi dan pelaporan; 6) pengawasan internal; 7) hutang dan investasi publik; 8) pengelolaan aset, dan 9) pengawasan eksternal. Implementasi kesembilan bidang tersebut diatur melaluisejumlah peraturan perundangan dalam bentuk; Undang-undang, Peraturan Pemerintah, Peraturan Menteri, Peraturan Daerah, dan peraturan turunanan lainnya. Tujuan studi PFM di Kabupaten Merauke adalah untuk mendapat gambaran komprehensif tentang tingkat kinerja implementasi bidangbidang PFM dimaksud dengan standar pada peraturan perundangan yang memayunginya. Kegunaan studi ini adalah untuk meningkatkan kapasitas pengelolaan keuangan daerah dalam rangka mengoptimalkan manfaat pembangunan daerah di Kabupaten Merauke.

\section{METODE PENELITIAN}

\section{Pendekatan Studi}

Secara garis besarnya pendekatan yang digunakan dalam studi ini terdiri atas dua bagian yakni pendekatan kuantitatif dan pendekatan kualitatif. Yang dimaksud dengan pendekatan kuantitatif adalah metode yang digunakan untuk menganalisis informasi yang dapat dikuantitatifkan atau data yang dapat diukur dan dimanipulasi misalnya dalam bentuk 
persamaan, tabel, grafik. Pendekatan kuantitatif dalam studi ini digunakan untuk: mempelajari berbagai kecenderungan, meramalkan dampak kebijakan yang diambil dan memperkirakan persoalan-persoalan yang potensial terjadi, serta menjadi dasar pertimbangan dalam pengembangan berbagai alternatif rencana yang akan diambil. Metode yang digunakan dalam pendekatan ini adalah statistik deskriptif kuantitatif yang bertujuan untuk membuat pencandraan atau deskripsi secara sistematis, faktual dan akurat mengenai fakta-fakta dan sifat-sifat populasi atau daerah tertentu.

Sedangkan pendekatan kualitatif adalah suatu proses dan pemahaman studi yang berdasarkan pada metodologi yang menyelidiki suatu fenomena sosial dan masalah manusia. Pada pendekatan ini dibuat suatu gambaran kompleks, meneliti kata-kata, laporan terinci dari berbagai pandangan, dan melakukan studi pada situasi yang alami. Adapun metoda yang diterapkan dalam pendekatan kualitatif kali ini adalah studi kasus yakni suatu studi yang mengeksplorasi suatu masalah dengan batasan terperinci, memiliki pengambilan data yang mendalam, dan menyertakan berbagai sumber informasi. Studi ini dibatasi oleh waktu dan tempat, dan kasus yang dipelajari berupa program, peristiwa, aktivitas, atau individu

\section{Metode dan Teknik Pengumpulan Data}

Metode yang digunakan dalam studi PFM (Public Financial Management) ini adalah metode survey, dengan teknik pengumpulan data menggunakan kuesioner yang disusun secara terbuka untuk memandu indepth interview terhadap responden yang telah ditetapkan menjadi sampel. Adapun metode sampling yang digunakan adalah nonrandom sampling yaitu purposive sampling dimana sampel diambil berdasarkan pertimbangan-pertimbangan tertentu. Dalam hal ini mempertimbangkan tugas pokok dan fungsi berdasarkan peraturan perundang-perundangan yang berlaku terkait dan relevan dengan kajian 
yang dilaksanakan. Responden yang dimaksud mencakup SKPD, badan, bagian di lingkungan pemerintahan daerah antara lain Bappeda, Bagian Hukum Setda, bagian Keuangan Setda, bagian Humas Dinas Komunikasi dan Informasi, Seketaris DPRD, Bagian Akuntansi, Pembukuan dan Verifikasi BPKAD, Dinas Pendidikan, Dinas Kesehatan, Badan Pengawasan Daerah, Inspektorat Daerah, dan lain-lain. Untuk melakukan verifikasi pada setiap indepth interview digunakan teknik dokumentasi, dimana beberapa dokumen penting yang dibutuhkan dalam kajian PFM ini antara lain RPJMD, RKPD, Renstra-SKPD, Renja, RKA, APBD, KUA-PPAS, LRA, dan sebagainya.

\section{Instrumen Penelitian}

Instrumen penelitian yang digunakan dalam studi ini merujuk kepada panduan kajian PFM yang dikeluarkan oleh Bank Dunia dan Kementerian Dalam Negeri . Terdapat 9 bidang strategis, 25 sasaran dan 144 indikator yang dinilai. Ke-9 bidang strategis yang dimaksud adalah : (1) Kerangka Peraturan Perundangan Daerah; (2) Perencanaan Dan Penganggaran; (3) Manajemen Kas/Penatausahan; (4) Pengadaan Barang Dan Jasa; (5) Akuntansi Dan Pelaporan; (6) Pengawasan Intern; (7) Hutang Dan Investasi Publik; (8) Pengelolaan Aset, dan (9) Pengawasan Eksternal. Setiap bidang strategis tersebut kemudian dibagi menjadi antara 1 sampai 5 hasil, dan daftar indikator dicantumkan untuk setiap hasil. Hasil mewakili pencapaian yang dikehendaki dalam setiap bidang strategis, dan indikator digunakan untuk menilai bagaimana kinerja pemerintah kabupaten/kota dalam bidang tersebut.

\section{Metode Analisa}

Setiap responden diminta untuk menjawab "ya" atau "tidak" untuk setiap pernyataan yang diwakili oleh masing-masing indikator. Jawaban setuju ditambahkan untuk setiap hasil, dan skor dihitung berdasarkan persentase jawaban "ya". Untuk menjamin akurasi data, maka setiap jawaban "ya" harus didukung dengan dokumen terkait 
dan/atau diperiksa silang dengan responden tambahan. Skor diberikan untuk setiap bidang strategis dan lokasi survei, dan skor menyeluruh diberikan untuk setiap lokasi survei. Akan tetapi, interpretasi hasil berisiko menimbulkan subyektivitas, karena hasilnya sangat bergantung pada interpretasi pihak yang mengadakan survei. Ini adalah kelemahan yang dimiliki oleh kerangka kerja ini. Hasil perhitungan persentase pencapaian skor setiap sasaran dan Bidang Strategis akan berada pada kisaran $0.00 \%$ sampai $100.00 \%$, yang dibagi menjadi 5 (lima) kategori level kinerja pengelolaan keuangan publik sebagai berikut.

Tabel 1

Bobot Dan Level Kinerja Dalam Analisa PFM

\begin{tabular}{|c|l|c|}
\hline Bobot & \multicolumn{2}{|c|}{ Level Kinerja } \\
\hline $80-100 \%$ & Excellent/Fully acceptable & Sangat Baik \\
\hline $60-79 \%$ & Very Good/Substantially acceptable & Baik \\
\hline $40-59 \%$ & Good/Fairly acceptable & Cukup Baik \\
\hline $20-39 \%$ & Moderate/Partially acceptable & Kurang Baik \\
\hline $00-19 \%$ & Poor/ Not acceptable & Tidak Baik \\
\hline
\end{tabular}

Sumber : PERA Provinsi Papua (2013)

Data yang telah ditabulasi dan diolah kemudian dianalisis secara deskriptif menggunakan alat statistik deskriptif yaitu distribusi frekwensi, distribusi relatif, crosstab. Selain itu salah satu kekuatan dari metode analisa PFM ini adalah web analysis yang berbentuk jaring laba-laba atau diagram radar yang dapat digunakan untuk menganalisis ketimpangan antar atribut bidang PFM.

\section{HASIL DAN PEMBAHASAN}

\section{Kinerja Pendapatan Daerah Kabupaten Merauke}

Perkembangan pendapatan daerah kabupaten Merauke cenderung mengalami kenaikan yang cukup pesat selama periode 
2011-2014. Rata-rata setiap tahunnya pendapatan daerah Kabupaten Merauke adalah sebesar Rp. 1.446,76 milyar, dengan kenaikannya per tahun sekitar 14,29\%, dimana pada tahun 2011 2013 mengalami pertumbuhan yang sangat cepat yaitu dari $7,32 \%$ menjadi 20,18\%. Namun di tahun 2014 relatif melambat dari tahun sebelumnya menjadi $18,69 \%$, yang disebabkan karena adanya penurunan penerimaan bagi hasil pajak di tahun tersebut.

Gambar 1

Perkembangan dan Pertumbuhan Pendapatan Kabupaten Merauke Tahun 2011-2014
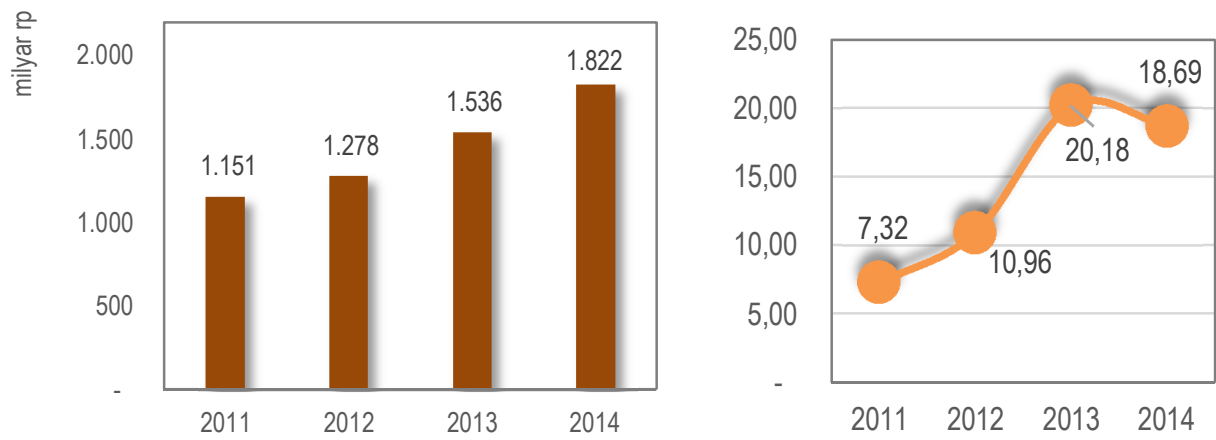

Sumber : BPS Merauke, 2015 (data diolah)

Efektifitas pengelolaan pendapatan di Kabupaten Merauke relatif mengalami penurunan, namun masih dalam kategori yang efektif. Tercermin selama tahun 2011-2014 tingkat efektifitas pendapatan (rasio realisasi dan target) di Kabupaten Merauke bisa mencapai 99,65\% per tahun yang masuk pada kategori efektif.

Pendapatan daerah per kapita di Kabupaten Merauke cenderung mengalami peningkatan. Pada tahun 2011 pendapatan daerah per kapita mencapai Rp. 5,57 juta per kapita, kemudian di tahun 2014 meningkat sebesar 24,02\% menjadi Rp. 6,91 juta per kapita. Dengan kata lain rata-rata per tahun naik sebanyak $8,01 \%$. Kecenderungan ini mengindikasikan bahwa jumlah pendapatan 
daerah yang diterima Kabupaten Merauke sepanjang tahun dapat mengimbangi pertambahan jumlah penduduk, sehingga upaya untuk meningkatkan pelayanan terhadap masyarakat melalui stimulus fiskal daerah semakin meningkat.

Gambar 2

Efektifitas Pendapatan Kabupaten Merauke

Tahun 2011-2014

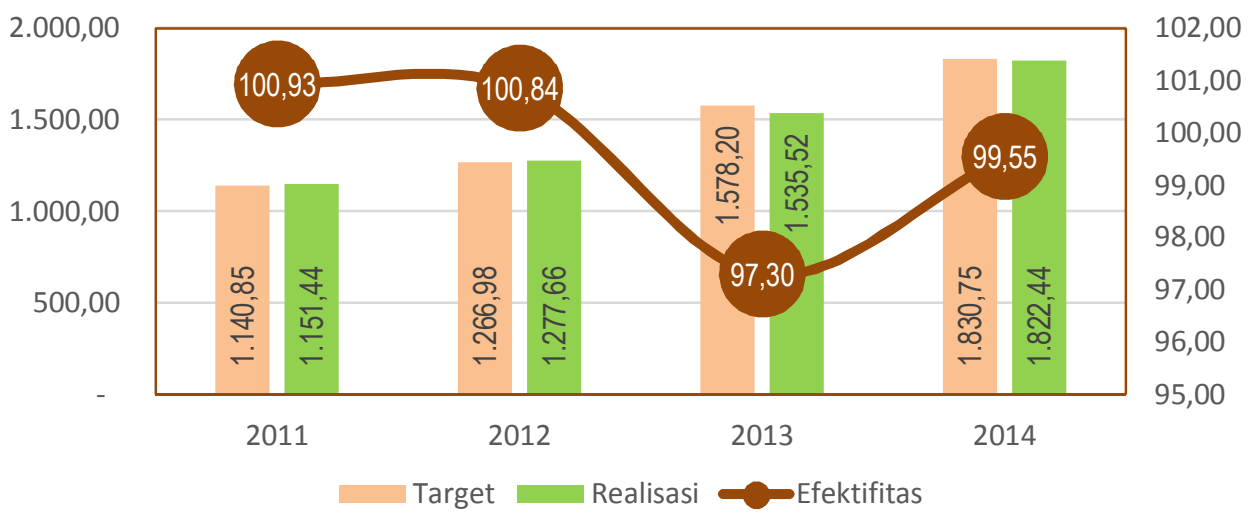

Sumber : BPS Merauke, 2015 (data diolah)

Gambar 3

Pendapatan Daerah Per Kapita Kabupaten Merauke Tahun 2011-2014

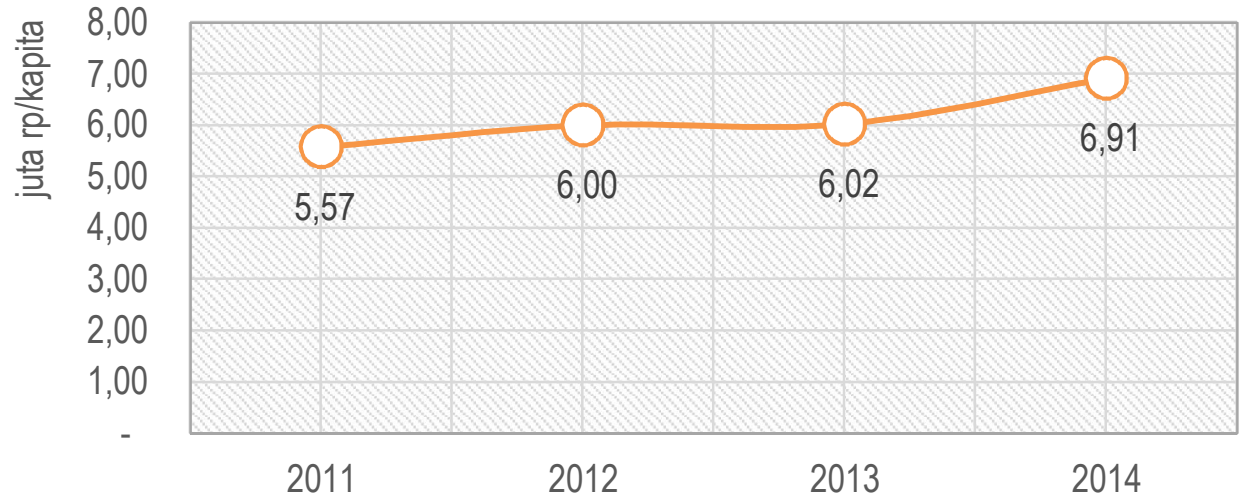

Sumber : BPS Merauke, 2015 (data diolah)

Peran PAD dalam pembentukan pendapatan Kabupaten Merauke meskipun kecil, namun cenderung mengalami 
peningkatan dari tahun ke tahun. Kontribusi PAD terhadap pendapatan daerah Kabupaten Merauke sepanjang tahun 20112014 rata-rata hanya 7,63\% per tahun, yang jauh di bawah Dana Perimbangan yang masih mendominasi pendapatan daerah di Kabupaten Merauke, dengan nilai dan persentase yang cenderung meningkat. Kontribusi dana perimbangan dalam struktur pendapatan daerah Kabupaten Merauke bisa mencapai $81,28 \%$ per tahun. Hal Ini mengindikasikan bahwa masih tingginya ketergantungan fiskal pemerintah Kabupaten Merauke terhadap pemerintah pusat.

\section{Gambar 4}

Struktur Pendapatan Daerah Kabupaten Merauke

Tahun 2011-2014

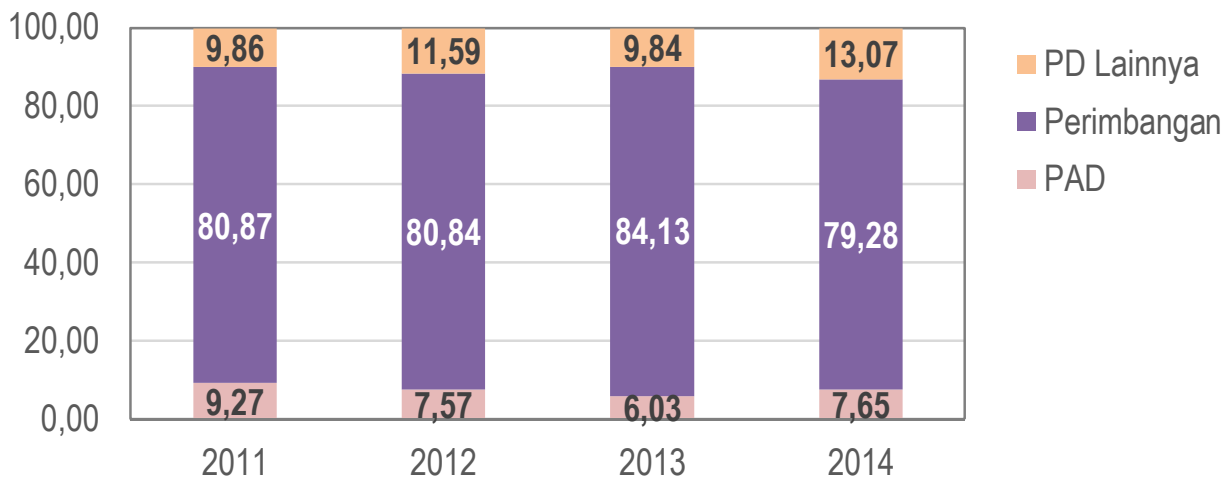

Sumber : BPS Merauke, 2015 (data diolah)

Semenjak maskapai penerbangan Merpati Nusantara Airlines dilikuidasi, kontribusi pengelolaan kekayaan daerah, terutama yang berasal dari bagian laba atas penyertaan modal pada PT. Merpati Nusantara Airlines, menurun drastis. Pada tahun 2011 peranan dari pengelolaan kekayaan daerah masih sangat dominan, mencapai $52,40 \%$ terhadap PAD Kabupaten Merauke, atau sebesar Rp. 55,81 milyar. Namun di tahun 2014, setelah 
likuidasi PT. Merpati Nusantara Airlines kontribusinya terhadap PAD menurun tajam menjadi 9,87\% atau Rp. 13,77 milyar. Posisinya di tahun tersebut menjadi yang paling rendah, digantikan oleh Penerimaan Retribusi yang melonjak tajam hingga mencapai $55,81 \%$. Kemudian Lain-Lain PAD yang sah sebesar $23,42 \%$, dan Penerimaan Pajak sebesar 10,90\%. Peranan Retribusi Daerah yang begitu dominan di tahun 2014 tersebut merupakan suatu indikasi bahwa kinerja pendapatan yang bersumber dari pelayanan kepada masyarakat semakin membaik.

Gambar 5

Komposisi dan Proporsi Komponen Penerimaan Terhadap Total PAD Kabupaten Merauke Tahun 2011-2014

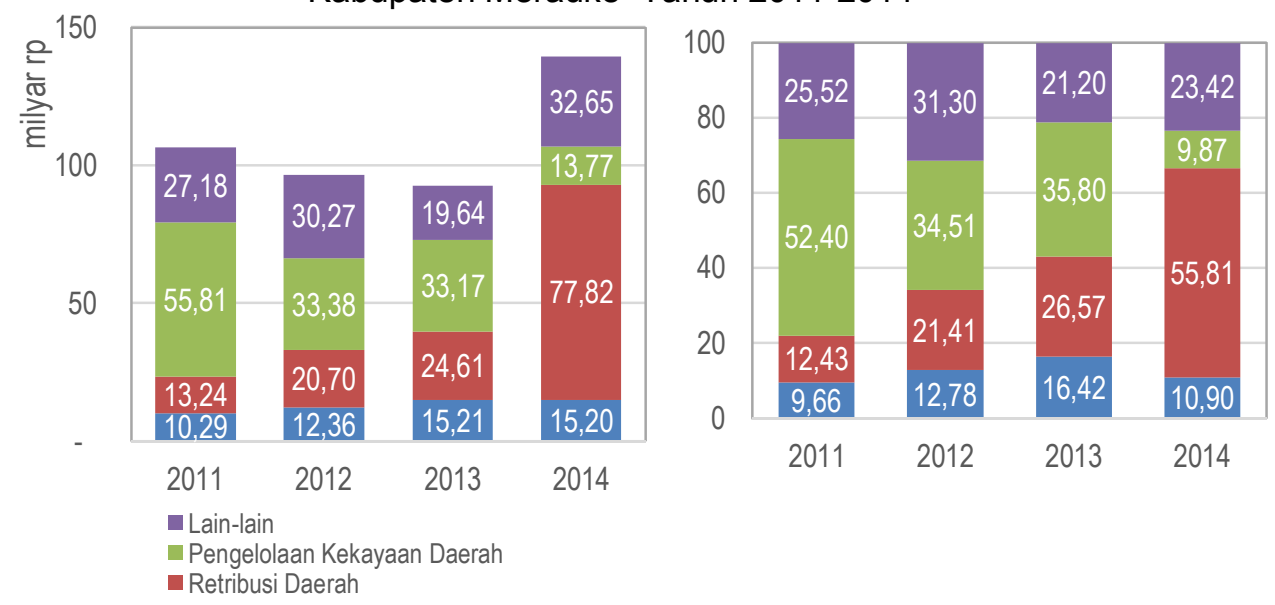

Sumber : BPS Merauke, 2015 (data diolah)

Walaupun peranan pajak dalam menciptakan PAD Kabupaten Merauke sangat rendah, namun tingkat efektifitasnya terlihat sangat tinggi. Hal ini menunjukan bahwa kinerja Dinas Pendapatan Daerah dalam mengelola pendapatan daerah sangat baik. Selama tahun 2011-2014 misalkan, efektifitas penerimaan Pajak Daerah dapat diwujudkan sebesar $110,78 \%$ per tahun, dengan fluktuasinya yang cukup beragam. 
Tabel 2

Efektifitas Penerimaan Pajak Daerah Kabupaten Merauke

Tahun 2011-2014

\begin{tabular}{|c|c|c|c|}
\hline Tahun & Target & Realisasi & Efektifitas \\
\hline 2011 & 8.605 .405 .607 & 10.285 .606 .498 & 119,52 \\
\hline 2012 & 11.514 .555 .985 & 12.364 .374 .586 & 107,38 \\
\hline 2013 & 12.870 .676 .852 & 15.210 .306 .837 & 118,18 \\
\hline 2014 & 15.502 .246 .621 & 15.197 .937 .677 & 98,04 \\
\hline Rata-Rata & 12.123 .221 .266 & 13.264 .556 .400 & 110,78 \\
\hline
\end{tabular}

Sumber : BPS Merauke, 2015 (data diolah)

Keluarnya Undang-Undang Nomor 28 Tahun 2009 mengenai Pajak Daerah dan Retribusi Daerah yang mulai berlaku secara efektif pada tahun 2010 telah memberikan peluang yang sangat besar bagi Kabupaten Merauke untuk meningkatkan penerimaan pajak daerah. Terutama dari penerimaan PBB, perolehannya meningkat drastis dan sangat dominan. Sebelum adanya UU Nomor 28 tersebut, PBB diserahkan sepenuhnya ke pemerintah pusat. Kemudian setelah diberlakukan undang-undang baru tersebut terlihat andil PBB dalam komposisi penerimaan Pajak Daerah Kabupaten Merauke sangat mencolok, misalkan di tahun 2014 mencapai 25,86\%, mengalahkan penerimaan Pajak Mineral Bukan Logam (Pajak Galian C) yang sebelumnya mendominasi penerimaan pajak daerah. Setelah itu adalah Pajak Restoran dan Pajak Penerangan Jalan masing-masing sebesar 19,05\% dan 19,18\%. Kemudian Pajak Mineral Bukan Logam sebesar 14,62\%. 
Gambar 6

Struktur Penerimaan Pajak Daerah Kabupaten Merauke Tahun 2014

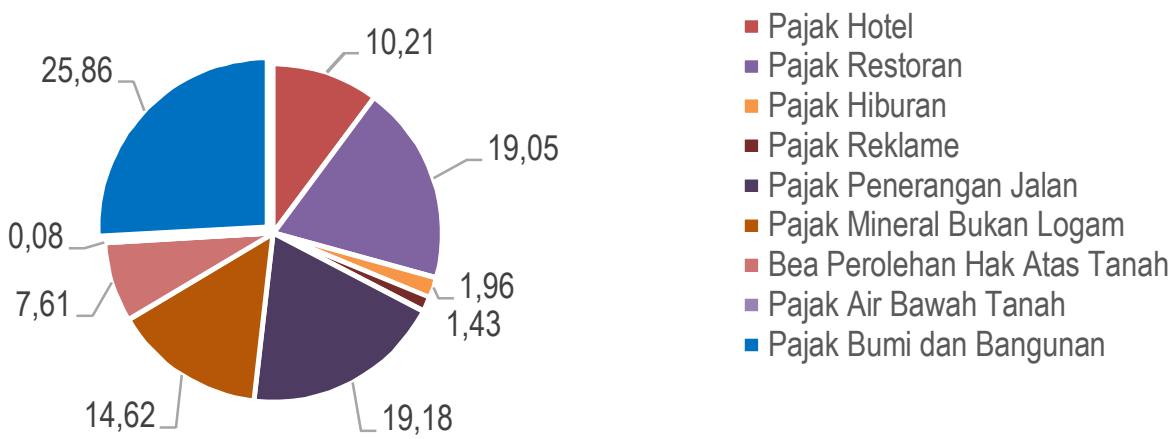

Sumber : BPS Merauke, 2015 (data diolah)

Peranan retribusi daerah terhadap total PAD Kabupaten Merauke jauh lebih besar di bandingkan pajak daerah, dan begitu juga dengan tingkat efektifitasnya relatif diatas pajak daerah. Perkembangan selama tahun 2010-2014 menunjukan kondisi demikian, dimana rata-rata pertahun efektifitas penerimaan retribusi daerah mencapai $107,91 \%$ yang masuk dalam kategori sangat efektifitas.

Gambar 7

Efektifitas Peneriman Retribusi Daerah Kabupaten Merauke Tahun 2010-1014

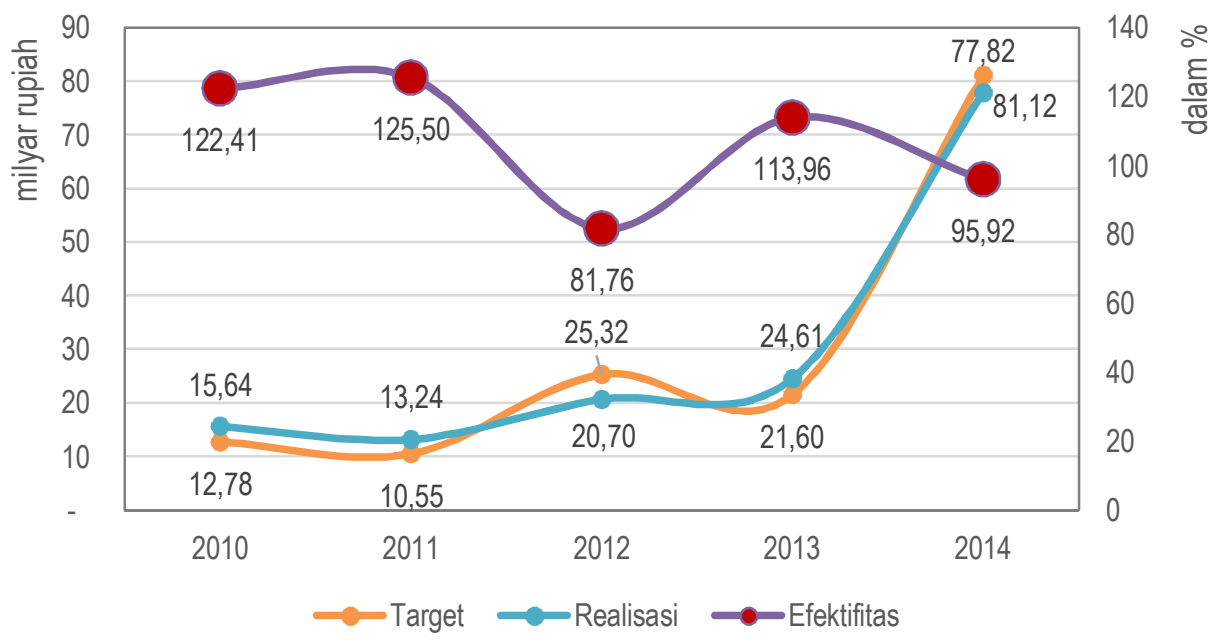

Sumber : BPS Merauke, 2015 (data diolah) 
Adapun jenis retribusi yang paling besar kontribusinya terhadap total penerimaan retribusi daerah adalah retribusi jasa umum, dimana retribusi jasa pelayanan kesehatan merupakan kontributor terbesar. Pada tahun 2014 misalkan, penerimaan retribusi pelayanan kesehatan sangat dominan mencapai Rp. 67.454 .805 .891 atau sekitar $86,86 \%$ terhadap total retribusi daerah, yang menyebabkan

Gambar 7

Struktur Penerimaan Retribusi Daerah Kabupaten Merauke Tahun 2014

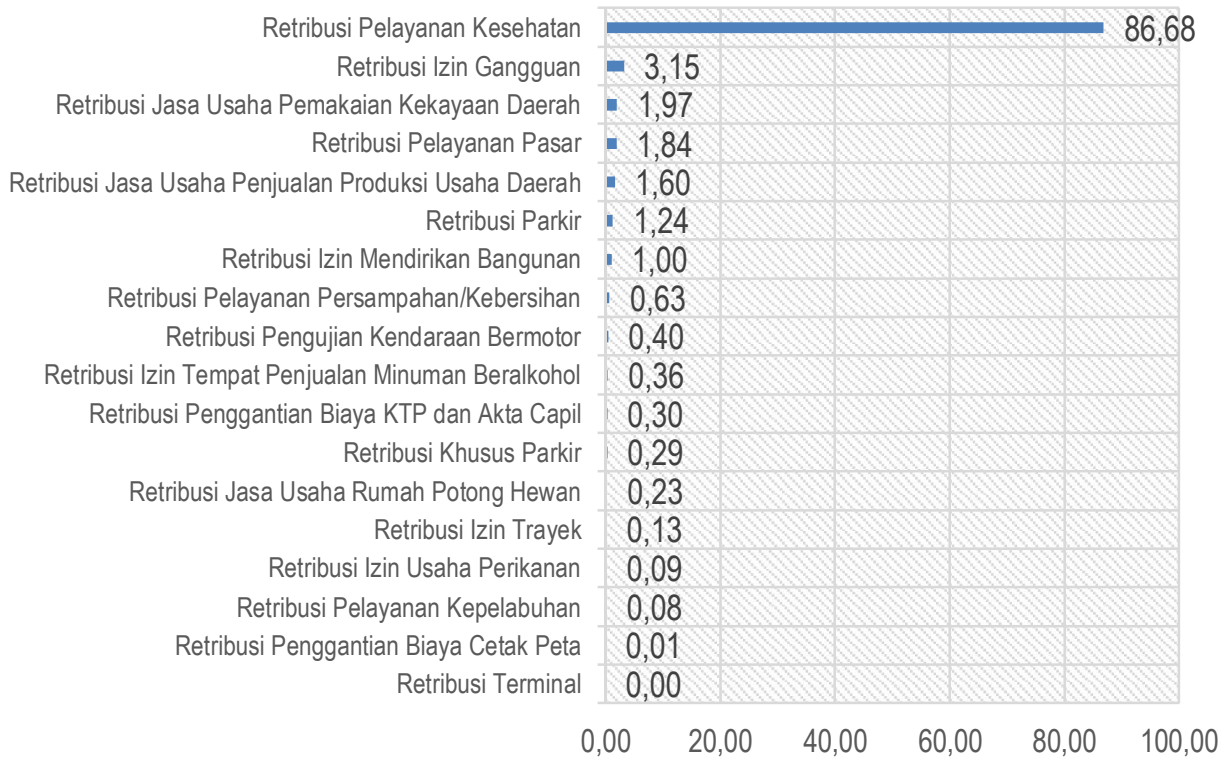

Sumber : BPS Merauke, 2015 (data diolah)

Rasio pendapatan dan belanja daerah di Kabupaten Merauke cenderung meningkat pada angka di atas $100 \%$. Fenomena ini mengindikasikan bahwa APBD Kabupaten Merauke dalam kondisi surplus. Misalkan untuk tahun 2011-2014 rata-rata rasio pendapatan dengan belanja daerah kurang lebih sebesar $101,20 \%$ per tahun. Meskipun demikian di tahun 2014 sempat mengalami penurunan. 
Gambar 8

Rasio Pendapatan Dan Belanja Daerah Di Kabupaten Merauke Tahun 2011-2014

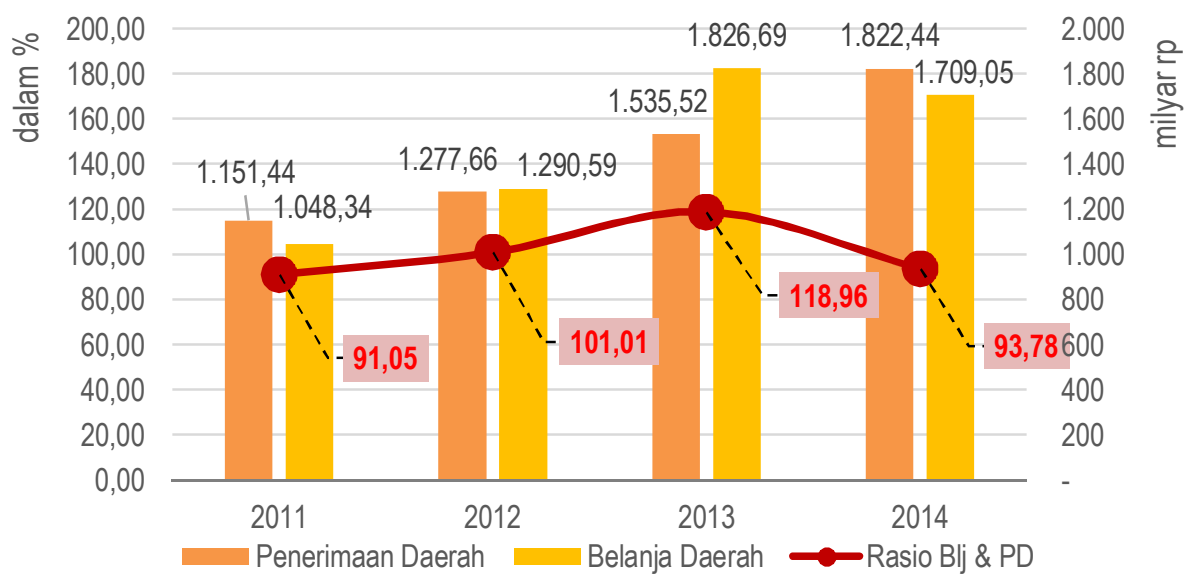

Sumber : BPS Merauke, 2015 (data diolah)

Rasio DAU dan belanja pegawai, serta DAU dan belanja wajib lainnya cenderung mengalami peningkatan setiap tahun. Namun demikian rasio belanja pegawai terhadap DAU setiap tahunnya sekitar 51,67\% per tahun sepanjang tahun 2011-2014. Sedangkan terhadap belanja lainnya, rata-rata pertahun sebesar $101,19 \%$. Kedua fenomena ini menunjukan bahwa DAU yang diperoleh Kabupaten Merauke setiap tahunnya lebih banyak digunakan untuk memenuhi belanja wajib sesuai dengan kebutuhan daerah.

Rasio PAD terhadap belanja modal cenderung mengalami penurunan setiap tahunnya. Rata-rata selama tahun 2011-2014 besaran rasionya mencapai $23,80 \%$ per tahun, yang mengindikasikan dari total PAD yang diterima setiap tahunnya ratarata hanya mampu menutupi belanja modal sekitar $23,80 \%$ saja. Berarti sisanya sebesar $76,20 \%$ dipenuhi dari sumber pendapatan lainnya. Upaya fiskal belum maksimal dilakukan oleh Kabupaten 
Merauke sehingga kemampuan PAD untuk memenuhi belanja modal masih sangat rendah, dan cenderung menurun.

Gambar 9

Rasio DAU Terhadap Belanja Pegawai Dan Belanja Wajib Lainnya

Di Kabupaten Merauke Tahun 2007-2011

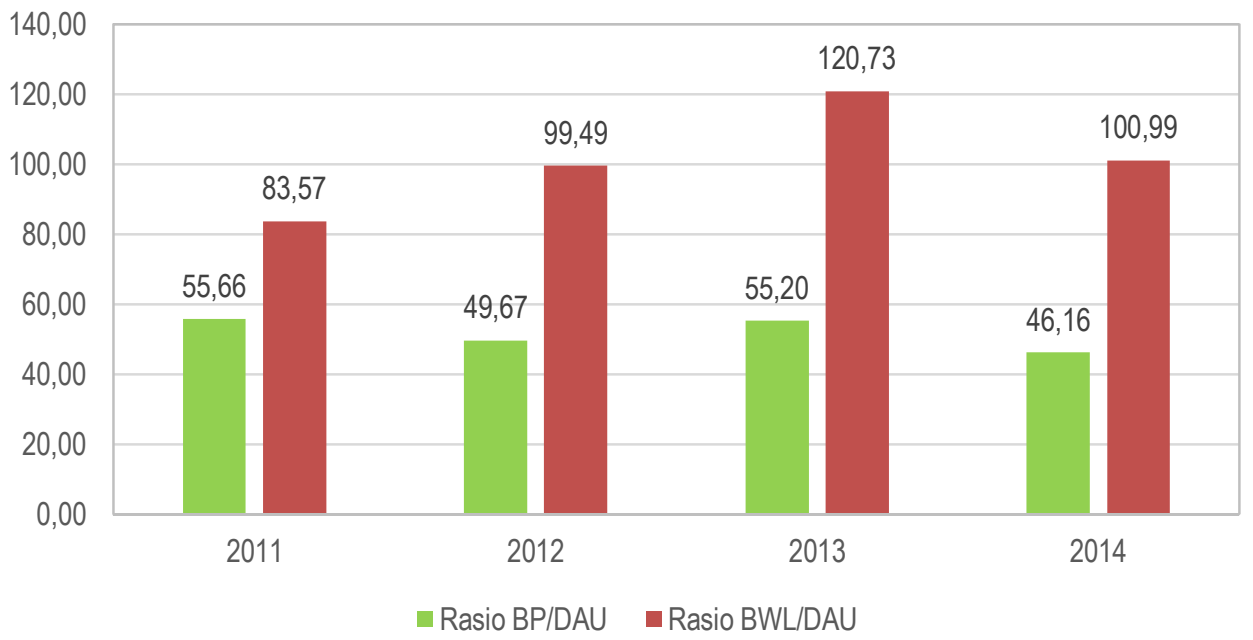

Sumber : BPS Merauke, 2015 (data diolah)

Gambar 10

Rasio PAD dan Belanja Modal Di Kabupaten Merauke Tahun 2011-2014

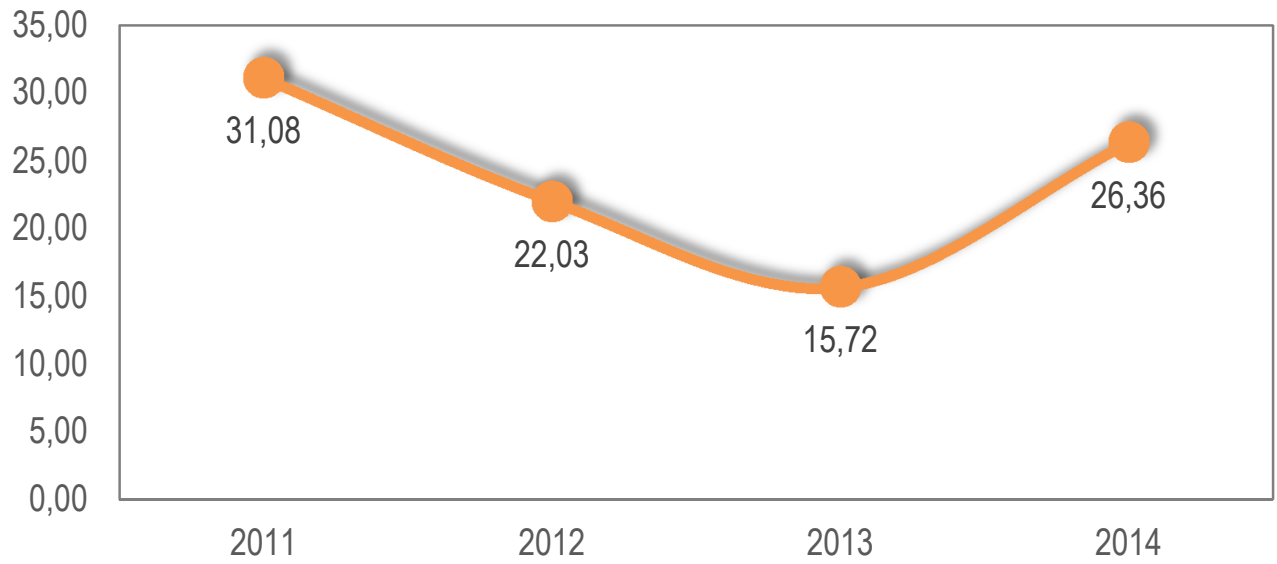

Sumber : BPS Merauke, 2015 (data diolah) 


\section{Profil Belanja Daerah Kabupaten Merauke}

Belanja daerah kabupaten Merauke mengalami peningkatan yang berfluktuatif, dengan daya serapnya yang cenderung rendah. Pertumbuhan realisasi belanja daerah selama tahun 2011-2014 mengalami kenaikan rata-rata $17,26 \%$ per tahun, dimana pada tahun 2014 tercatat realisasi belanja adalah sebesar Rp. 1.974.862,49 milyar atau Rp. 1,97 triliun. Terlihat juga bahwa perkembangan realisasi belanja selalu berbeda lebih rendah dengan anggaran perubahan. Perbedaan yang signifikan antara anggaran perubahan dengan realisasi tersebut disebabkan karena adanya peningkatan pada belanja tidak langsung. Kondisi ini juga menunjukkan bahwa daya serap anggaran yang rendah di kabupaten Merauke. Setiap tahunnya rata-rata daya serap belanja di Kabupaten Merauke hanya 84,20\%.

\section{Gambar 11}

Perkembangan Belanja dan Daya Serap Anggaran

Di Kabupaten Merauke Tahun 2011-2014

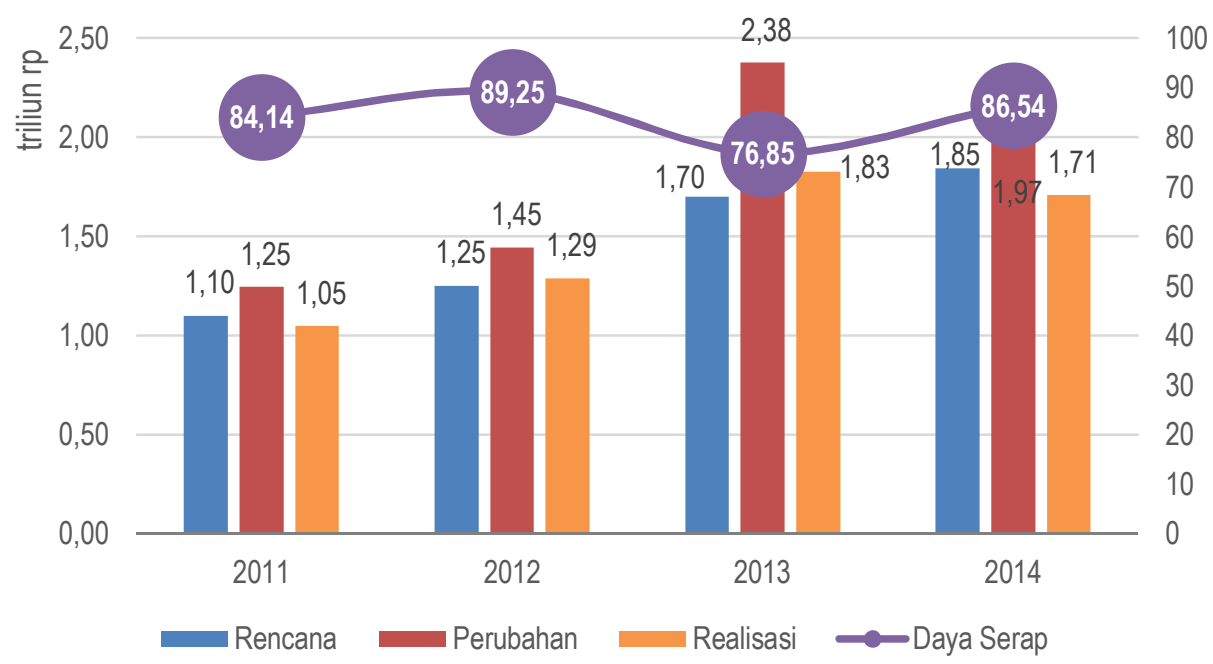

Sumber : BPS Merauke, 2015 (data diolah) 
Belanja perkapita Kabupaten Merauke mengalami kenaikan yang cukup tinggi per tahunnya. Pada tahun 2011 besarnya belanja per kapita mencapai Rp. 5,07 juta. Sampai dengan tahun 2013 terus mengalami peningkatan sebesar $13,59 \%$ per tahun. Selanjutnya di tahun 2014 mengalami penurunan sebesar $-9,52 \%$ dibandingkan tahun sebelumnya, namun masih tetap lebih tinggi dibandingkan tahun 2011, dimana belanja per kapita pada tahun 2014 mencapai Rp. 6,48 juta per kapita. Sehingga bila dibandingkan dengan tahun 2011, rata-rata mengalami kenaikan sebesar 7,81\% per tahun. Kondisi ini mengindikasikan bahwa upaya pemerintah untuk memberi pelayanan yang maksimal kepada masyarakat cenderung semakin baik sepanjang tahun 2011-2014.

Gambar 12

Belanja Per Kapita dan Tingkat Pertumbuhannya

Di Kabupaten Merauke Tahun 2011-2014

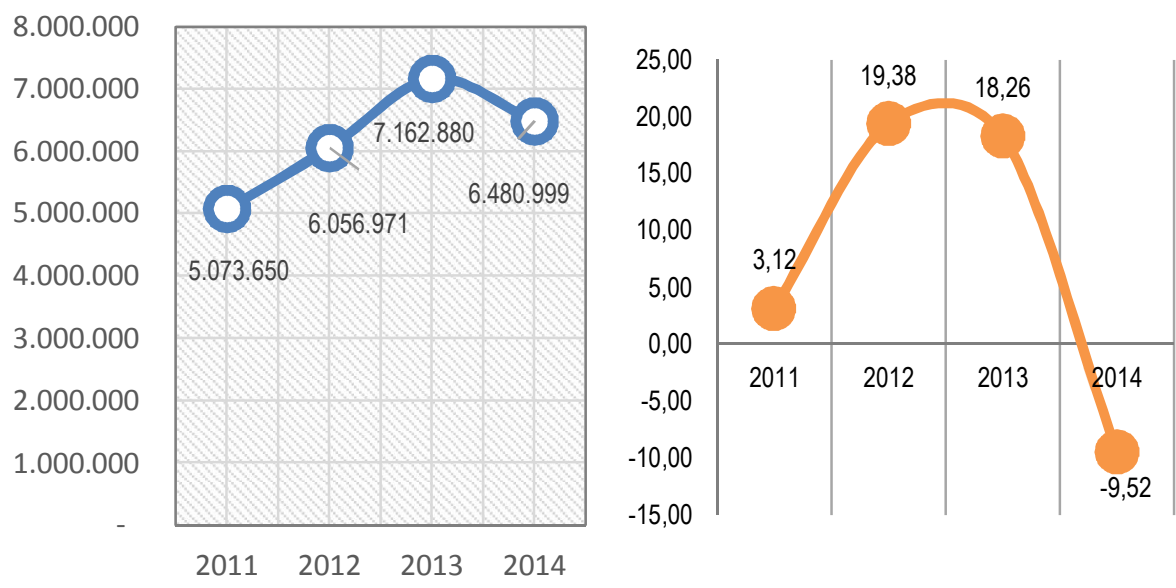

[a]. Belanja Per Kapita (Rp) [b]. Pertumbuhan Belanja Per kapita (\%)

Sumber : BPS Merauke, 2015 (data diolah) 
Belanja langsung dan belanja tidak langsung di Kabupaten Merauke besarannya berfluktuasi dengan kecenderungan yang meningkat. Rata-rata pertumbuhan total belanja daerah di Kabupaten Merauke sepanjang tahun 2011-2014 sebesar 19,40\% per tahun, dimana yang menjadi pemicunya selama ini adalah perkembangan belanja tidak langsung yang mampu tumbuh sebesar $22,64 \%$ per tahun untuk periode yang sama.Selain itu belanja tidak langsung juga mendapat porsi yang terbesar dalam komposisi belanja daerah, dengan rata-rata per tahun sekitar $61,64 \%$. Sedangkan untuk belanja langsung yang tumbuh lebih rendah sebesar $14,68 \%$ per tahun, mempunyai kontribusi sebanyak $38,36 \%$ per tahun terhadap perkembangan belanja daerah.

Tabel 3

Perkembangan Belanja Daerah Menurut Klasifikasi Belanja Di Kabupaten Merauke Tahun 2011-2014

\begin{tabular}{|c|c|c|c|c|c|}
\hline Klasifikasi Belanja & $\mathbf{2 0 1 1}$ & $\mathbf{2 0 1 2}$ & $\mathbf{2 0 1 3}$ & $\mathbf{2 0 1 4}$ & Rata-Rata \\
\hline Nilai (Rp milyar) & & & & & \\
\hline $\begin{array}{c}\text { Belanja Langsung } \\
\text { Belanja Tidak Langsung }\end{array}$ & 434.375 & 495.001 & 665.098 & 636.643 & 557.779 \\
\hline $\begin{array}{c}\text { Total Belanja } \\
\text { Proporsi (\%) }\end{array}$ & 1.048 .343 & 1.290 .589 & 1.826 .692 & 1.709 .046 & 1.468 .668 \\
\hline Belanja Langsung & 41.43 & 38.35 & 36.41 & 37.25 & 38.36 \\
\hline $\begin{array}{c}\text { Belanja Tidak Langsung } \\
\text { Pertumbuhan (\%) }\end{array}$ & 58.57 & 61.65 & 63.59 & 62.75 & 61.64 \\
\hline $\begin{array}{c}\text { Belanja Langsung } \\
\text { Belanja Tidak Langsung }\end{array}$ & & 13.96 & 34.36 & -4.28 & 14.68 \\
\hline Total Belanja & & 29.58 & 46.00 & -7.68 & 22.64 \\
\hline
\end{tabular}

Sumber : BPS Merauke, 2015 (data diolah)

Belanja modal di kabupaten Merauke cenderung meningkat, namun relatif masih dibawah belanja pegawai dalam struktur belanja Kabupaten Merauke. Proporsi belanja modal terhadap total 
belanja selama tahun 2011-2014 rata-rata sebesar 32,46\%, dengan nilainya Rp. 475,03 milyar per tahun. Sedangkan untuk belanja pegawai jika dilihat dari nilainya terus mengalami peningkatan, kecuali pada tahun 2014 mengalami penurunan. Rata-rata belanja pegawai adalah sebesar Rp 489,85 milyar atau $34 \%$ per tahun dari total belanja, dengan kecenderungan yang terus menurun.

\section{Gambar 13}

Komposisi dan Proporsi Belanja Terhadap Total Belanja Menurut Klasifikasi Ekonomi Di Kabupaten Merauke Tahun 2011-2014
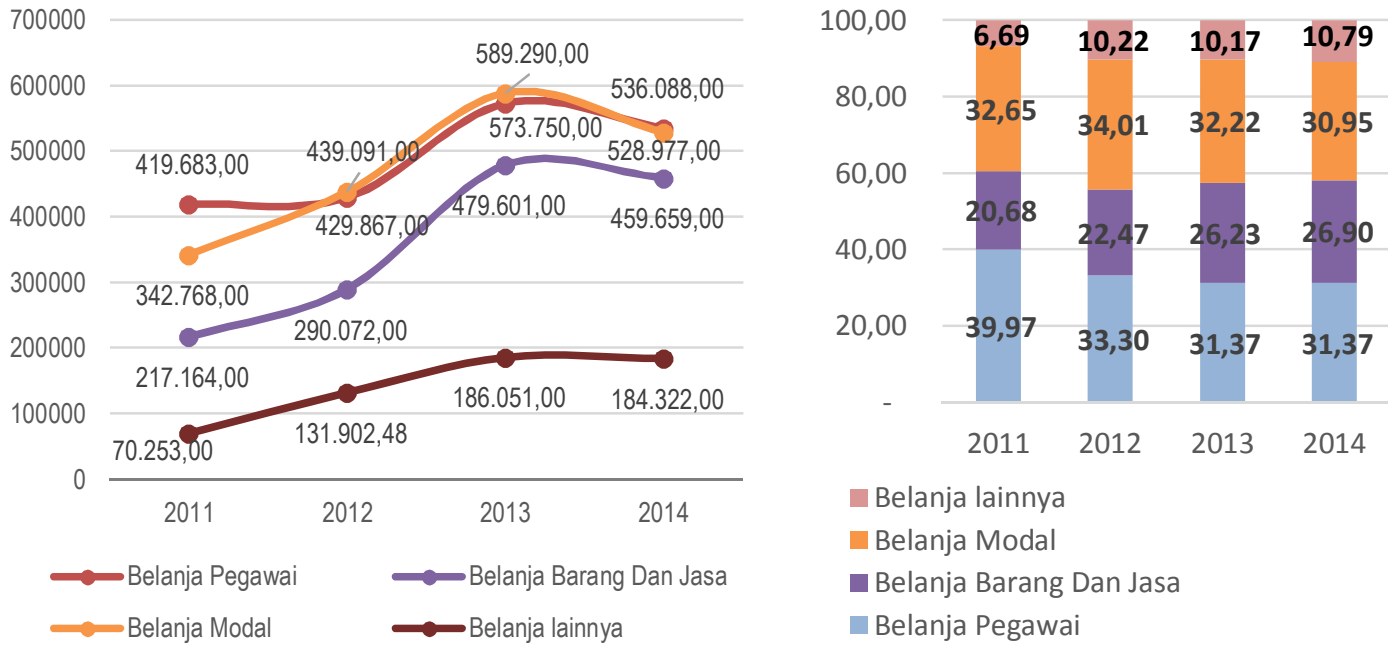

Sumber : BPS Merauke, 2015 (data diolah)

\section{Analisis Public Finance Management Kabupaten Merauke \\ Gambaran Umum Pengelolaan Keuangan Daerah}

Pengelolalaan keuangan publik di kabupaten Merauke secara umum dapat dikatakan sudah dilaksanakan dengan cukup baik. Hasil pengolahan data primer menggunakan analisa PFM (Public Finance Management) menunjukan bahwa dari total statement yang dinilai mencakup 9 bidang didapat skor secara 
keseluruhan sebesar $52 \%$. Dengan skor yang paling tinggi adalah pada bidang perencanaan, pengelolaan kas, pengadaan, serta akuntansi dan pelaporan

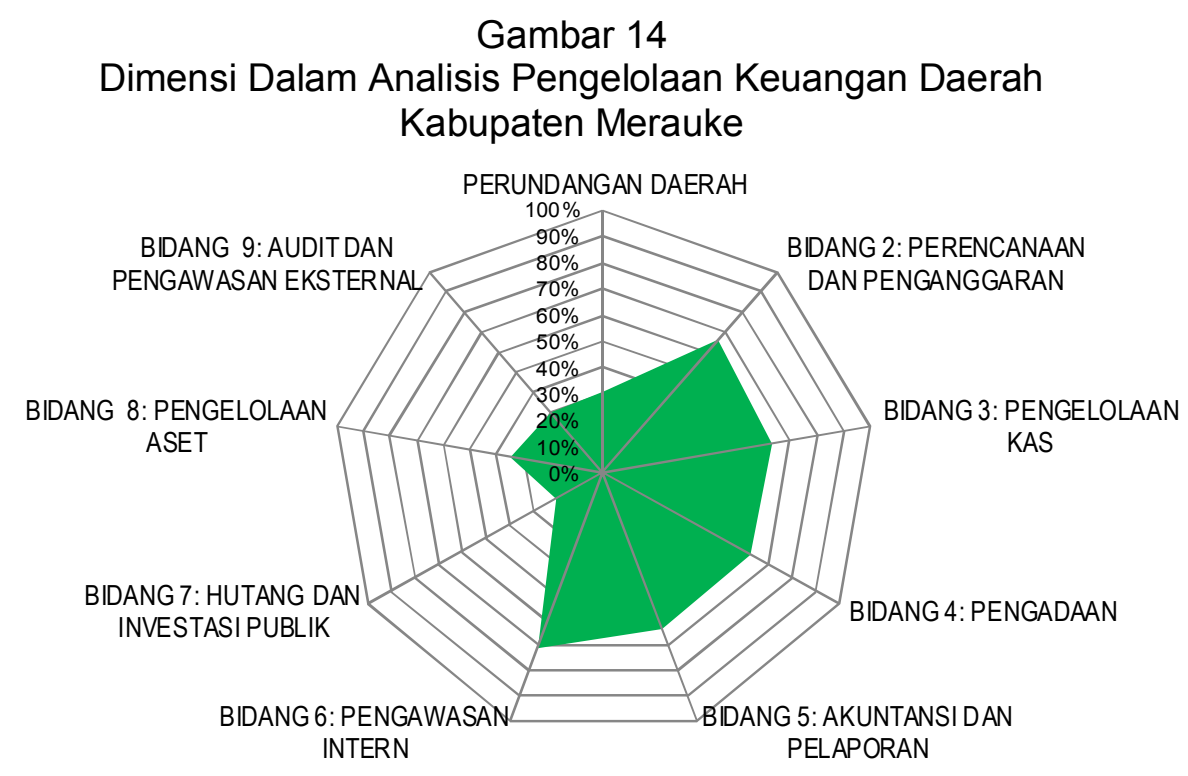

Sumber : data diolah (2014)

\section{Perencanaan Dan Penganggaran}

Proses perencanaan dan penganggaran dapat dikategorikan baik. Total skor bidang sebesar $66 \%$, dimana ada tiga outcome yang dianggap berkontribusi cukup signifikan yaitu (i) perencanaan dan penganggaran multi tahun dianggap sudah disusun di kabupaten Merauke, skornya 83\%, (ii) dalam dokumen RPJM, KUA APBD dan PPAS TA 2012 sudah dicantumkan berbagai indikator yang dapat diukur secara kuantitatif, sehingga target anggaran yang layak dan berdasarkan proses yang realistis mendapat skor 60\%, dan (iii) dalam RKA APBD tahun 2012 telah dimuat indidkator-indikatior yang terukur yang merujuk pada KUA dan PPAS, selain itu juga sudah menyusun analisis standar biaya 
untuk digunakan sebagai pedoman dalam menyusun APBD TA 2012.

Gambar 15

Skor Penilaian Bidang Perencanaan dan Penganggaran

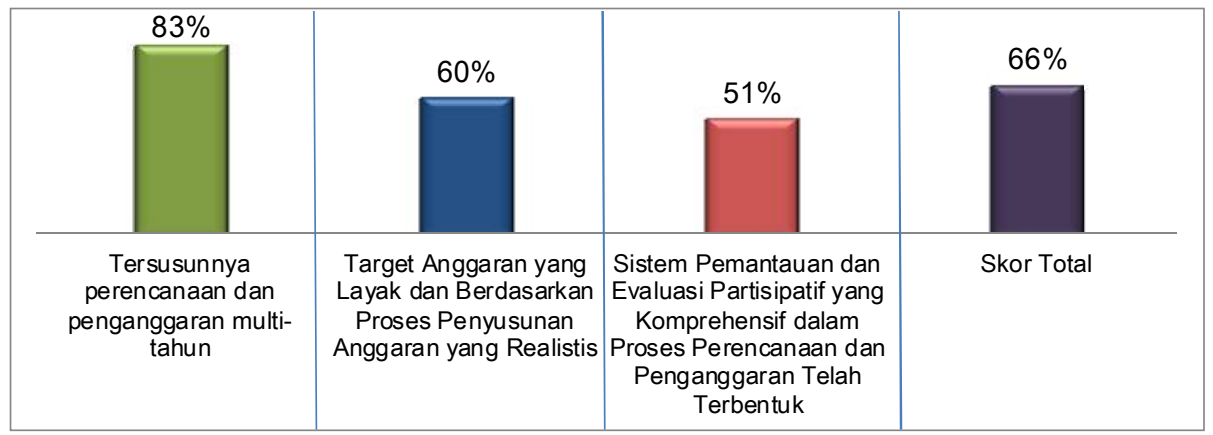

Sumber : data diolah (2014)

Penentuan target anggaran sudah dilakukan dengan layak dan proses penyusunannya pun cukup realisitis dan dinilai baik. Total skornya adalah $60 \%$. Hal ini bisa dilihat dari perbedaan antara APBD Induk dan APBD-P yang kurang dari 10\%, kemudian dalam dokumen Renstra dan Renja SKPD sudah memuat pagu indikatif yang mempertimbangkan keterbasan sumber daya. Namun disisi lain masih terdapat defisit anggaran dalam 3 tahun terakhir sebesar 0,52\% dari PDRB dan masih terdapat perbedaan total anggaran belanja dengan realisasi APBD TA 2011 yang di atas 10\%.

Sistem pemantauan dan evaluasi partisipasi yang komprehensif dalam peroses perencanaan penganggaran telah berjalan dengan cukup baik. Total skor adalah 51\%. Walaupun sudah terdapat proses evaluasi atas RKA SKPD dalam hal kesesuaian antara KUA dan PPAS, namun masyarakat belum dilibatkan dalam proses evaluasi dan juga masyarakat tidak mudah untuk dapat mengakses dokumen perencanaan dan penganggaran di SKPD di Kabupaten Merauke 
Berbeda dengan proses perencanaan dan penganggaran yang dinilai baik, untuk kerangka peraturan perundangan daerah terlihat belum optimal dilaksanakan. Skor bidang yang diperoleh hanya sebesar $31 \%$. Beberapa elemen outcome yang dianggap membuat penilaian di bidang ini menjadi rendah adalah mengenai peraturan pengelolaan keuangan daerah, serta transparansi dan partisipasi masyarakat. Walaupun peraturan perundangan tentang pengelolaan keuangan daerah sudah ditetapkan namun penetapan peraturan perundangan tentang RPJM, RKPD, KUA, PPAS, Renja masih belum tepat waktu. Peraturan kepala daerah tentang standar harga sudah ditetapkan namun Analisis Standar Belanja belum ditetapkan di Kabupaten Merauke. Kerangka peraturan perundangan yang terkait dengan penegakan hukum dan struktur organisasi sudah efektif pelaksanaannya dengan skor $83 \%$, namun kerangka perundangan tentang transparansi dan partisipasi masyarakat belum ditetapkan dan masyarakat tidak memiliki akses pada sidang-sidang DPRD mengenai APBD.

. Gambar 16

Skor Penilaian Bidang Kerangka Peraturan Daerah

\begin{tabular}{|l|c|c|c|}
\hline & $83 \%$ & \\
\hline $\begin{array}{c}\text { Pengelolaan Keuangan } \\
\text { Daerah }\end{array}$ & $\begin{array}{c}\text { Penegakan Hukum dan } \\
\text { Struktur Organisasi yang } \\
\text { Efektif }\end{array}$ & $\begin{array}{c}\text { Meningkatkan } \\
\text { Transparansi dan } \\
\text { Partisipasi Masyarakat }\end{array}$ & Skor total \\
\hline
\end{tabular}

Sumber : data diolah (2014)

\section{Pelaksanaan Anggaran}

Secara keseluruhan penerapan praktik-praktik manajemen kas yang efektif guna memastikan pengelolaan dana yang efisien dalam pelayanan sudah berjalan baik dengan sistem pemungutan 
dan penagihan yang efisien. Semua ini menyebabkan penilaian terhadap bidang pengelolaan kas memperoleh skor 63\%. Penerimaan kas, pembayaran kas, serta surplus kas temporer sudah dikelola dan dikendalikan secara efisien (skor 64\%), demikian juga upaya-upaya untuk peningkatan dan penanganan manajemen pendapatan sudah sangat baik pelaksanaannya (skor $60 \%$ ). Untuk Kebijakan, prosedur, dan pengendalian dalam mendorong pengelolaan kas yang efisien walaupun telah dibentuk tetapi belum berjalan dengan optimal (skor 41\%).

\section{Gambar 17}

Skor Penilaian Bidang Pengelolaan Kas

\begin{tabular}{|c|c|c|c|c|}
\hline & $64 \%$ & & & \\
\hline $\begin{array}{c}\text { Kebijakan, Prosedur, } \\
\text { dan Pengendalian } \\
\text { untuk Mendorong } \\
\text { Pengelolaan Kas } \\
\text { yang Efisien Telah } \\
\text { Dibentuk }\end{array}$ & $\begin{array}{c}\text { Penerimaan Kas, } \\
\text { Pembayaran Kas, } \\
\text { Serta Surplus Kas } \\
\text { Temporer Dikelola } \\
\text { dan Dikendalikan } \\
\text { Secara Efisien }\end{array}$ & $\begin{array}{c}\text { Terdapat Sistem } \\
\text { Penagihan dan } \\
\text { Pemungutan } \\
\text { Pendapatan Daerah } \\
\text { yang Efisien }\end{array}$ & $\begin{array}{c}\text { Peningkatan dan } \\
\text { Penanganan } \\
\text { Manajemen } \\
\text { Pendapatan }\end{array}$ & \\
\hline
\end{tabular}

Sumber : data diolah (2014)

Proses pengadaan barang di Kabupaten Merauke sudah berjalan dengan baik. Total skornya adalah 63\%.Kegiatan pengadaan barang dan jasa daerah yang menghasilkan peningkatan kompetisi, menyediakan peningkatan nilai uang (penghematan) belanja daerah, menciptakan transparansi yang lebih baik, serta menghasilkan akuntabilitas yang lebih baik sudah berjalan dengan efisien di kabupaten Merauke.

Pejabat pengadaan (PPK dan Unit Layanan Pengadaan) yang memiliki sertifikat pengadaan barang/jasa masih terbatas di Kabupaten Merauke. Belum terdapat usulan kebutuhan barang daerah yang dibahas bersama antara pengguna barang (SKPD) 
dan pengelola barang dengan memperhatikan spesifikasi barangdan standar harga. Unit Layanan Pengadaan yang melaksanakan pengadaan barang dan jasa di Pemda Kabupaten Merauke belum terbentuk dan tidak terdapat catatan rekam jejak (daftar hitam) yang dibuat oleh ULP mengenai rekanan yang nakal dan dilaporkan ke LKPP setiap tahun serta belum terdapat sistem pengawasan/audit oleh Penanggung jawab Anggaran atas pengadaan barang yang dilaksanakan melalui swakelola.

Gambar 18

Skor Penilaian Bidang Akuntansi dan Pelaporan

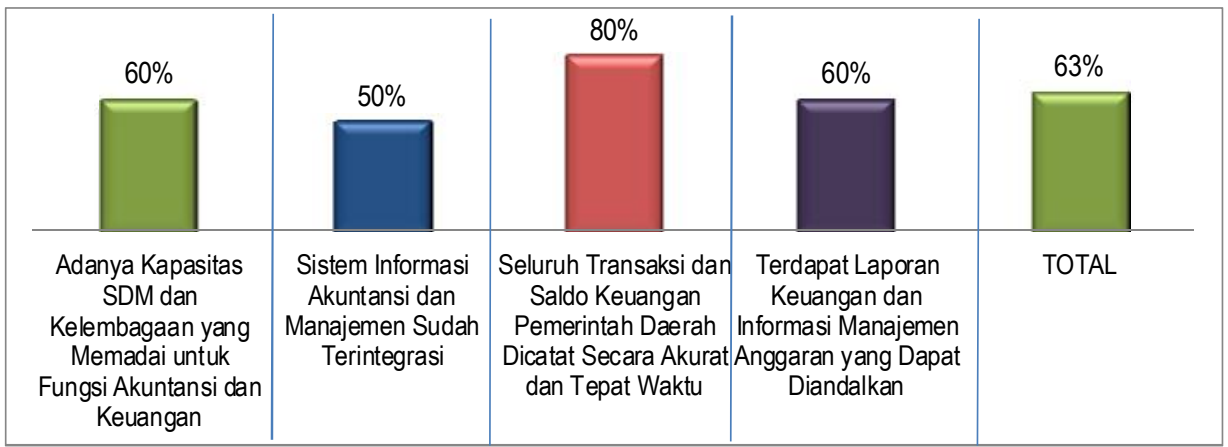

Sumber : data diolah (2014)

Sistem akuntansi yang menjamin terlaksananya akuntansi yang tepat atas seluruh transaksi keuangan dan menghasilkan laporan keuangan eksternal dan internal sudah dapat diandalkan, wajar dan tepat waktu. Total skornya adalah dengan skor $63 \%$. Kapasitas SDM dan kelembagaan sudah memadai untuk fungsi akuntansi dan keuangan di kabupaten Merauke, namun untuk pejabat Penatausahaan Keuangan (PPK) SKPD yang berlatar belakang pendidikan akuntansi belum memadai. Sistem informasi akuntansi dan manajemen belum terintegrasi dengan cukup baik disebabkan karena laporan keuangan dan laporan kinerja belum dihasilkan dalam satu sistem.Transaksi dan saldo keuangan pemerintah daerah sudah dicatat dengan akurat dan tepat waktu 
demikian juga untuk laporan keuangan dan informasi manajemen anggaran sudah dapat diandalkan.

Pengelolaan yang hati-hati atas pinjaman daerah, investasi daerah, serta kepemilikan dalam BUMD belum cukup baik pelakasanaannya. Total skornya adalah $20 \%$. Kebijakan, prosedur, serta pengendalian dan pinjaman investasi daerah yang memperhitungkan resiko belum ditetapkan dan dilaksanakan. Demikian juga dengan kebijakan, prosedur dan pengelolaan penerimaan hibah belum ditetapkan dan dilaksanakan di Kabupaten Merauke.

Gambar 19

Skor Penilaian Bidang Hutang dan Investasi Publik

\begin{tabular}{|c|c|c|}
\hline \multicolumn{1}{|c|}{$20 \%$} & & \multicolumn{2}{|c|}{$20 \%$} \\
\hline $\begin{array}{c}\text { Kebijakan, Prosedur, serta } \\
\text { Pengendalian dan Pinjaman } \\
\text { Investasi Daerah yang } \\
\text { Memperhitungkan Resiko Telah } \\
\text { Ditetapkan dan Dilaksanakan }\end{array}$ & $\begin{array}{c}\text { Kebijakan, Prosedur dan } \\
\text { Pengelolaan Penerimaan Hibah } \\
\text { telah ditetapkan dan dilaksanakan }\end{array}$ & Skor Total \\
\hline
\end{tabular}

Sumber : data diolah (2014)

Peningkatan keefektifan pengelolaan aset daerah melalui perencanaan dan pengelolaan aset jangka panjang menjamin terciptanya layanan terbaik dalam mendukung kelancaran aktifitas pemerintahan belum dilakukan dengan baik. Total skornya adalah $35 \%$. Hal ini dapat dilihat dari belum terdapatnya kebijakan yang mengatur penggunaan dan pemanfaatan aset daerah yang mendukung tertib pengelolaan aset daerah, Kebijakan dan prosedur pemeliharaan asset juga belum dilakukan dan terintegrasi dengan proses perencanaan daerah untuk memastikan kondisi aset selalu siap digunakan. Juga belum terdapat kebijakan, sistem 
dan prosedur pencatatan, perolehan, penilaian, pemindahtangan dan penghapusan dan pelaporan barang daerah yang efektif.

Gambar 20

Skor Penilaian Bidang Pengelolaan Aset

\begin{tabular}{|c|c|c|c|}
\hline & $\mid 20 \%$ & & \\
\hline $\begin{array}{c}\text { Terdapat kebijakan yang } \\
\text { mengatur penggunaan dan } \\
\text { pemanfaatan aset daerah } \\
\text { yang mendukung tertib } \\
\text { pengelolaan aset daerah }\end{array}$ & $\begin{array}{c}\text { Kebijakan dan prosedur } \\
\text { pemeliharaan asset dilakukan } \\
\text { dan terintegrasi dengan } \\
\text { proses perencanaan daerah } \\
\text { untuk memastikan kondisi } \\
\text { aset selalu siap digunakan }\end{array}$ & $\begin{array}{c}\text { Terdapat kebijakan, sistem } \\
\text { dan prosedur pencatatan, } \\
\text { perolehan, penilaian, } \\
\text { pemindahtangan dan } \\
\text { penghapusan dan pelaporan } \\
\text { barang daerah yang efektif }\end{array}$ & Skor Total \\
\hline
\end{tabular}

Sumber : data diolah (2014)

\section{Pengawasan Dan Akuntabilitas}

Secara umum pengawasan internal yang dilakukan di Kabupaten merauke sudah berjalan dengan cukup baik, walaupun SDM yang berkualifikasi jabatan fungsional auditor dan yang berlatar belakang akuntansi jumlahnya belum memadai. Total skornya adalah $71 \%$. Inspektorat secara reguler juga sudah menguji sistem pengendalian intern yang ada dan implementasinya. Program dan prosedur audit sudah secara reguler dikaji ulang dan direvisi, laporan audit internal juga sudah menyatakanruang lingkup pemeriksaan sebelum memberikan pendapat/kesimpulan, dan laporan audit internal dikirimkan kepada bupati dengan tembusan ke inspektorat provinsi dan BPK.

Gambar 21

Skor Penilaian Bidang Pengawasan Internal

\begin{tabular}{|c|c|c|c|}
\hline \multicolumn{1}{|c|}{} & S6\% & & \\
\hline $\begin{array}{c}\text { Bawasda Terorganisir dan } \\
\text { Diberdayakan untuk } \\
\text { Beroperasi dengan Efektif }\end{array}$ & $\begin{array}{c}\text { Standar dan Prosedur } \\
\text { Audit Internal yang } \\
\text { Diaplikasikan Dapat } \\
\text { Diterima }\end{array}$ & $\begin{array}{c}\text { Temuan Audit Internal } \\
\text { Ditindaklanjuti dengan } \\
\text { Segera }\end{array}$ & Skor Total \\
\hline
\end{tabular}

Sumber : data diolah (2014) 
Temuan audit internal di kabupaten Merauke selalu segera ditindaklanjuti. Sehingga memperoleh skor 100\%. Laporan internal audit ditujukan kepada Kepala Daerah dan ditembuskan ke pihakpihak yang terkait. Temuan audit telah ditindaklanjuti oleh bupati setelah diterimanya LHP (Laporan Hasil Pemeriksaan).

Audit eksternal guna menjamin efektivitas dan akuntabilitas pemerintah daerah, belum optimal dilaksanakan. Total skornya adalah 53\%. Laporan keuangan tahunan Kabupaten merauke lambat disampaikan kepada BPK, Demikian juga laporan keuangan tidak dipublikasikan misalnya melalui media massa setempat dan pada papan pengumuman resmi atau melalui web site. Masyarakat juga tidak dapat menghadiri sidang DPRD yang mendiskusikan laporan pertanggungjawaban dan hasil audit BPK.

Gambar 22

Skor Penilaian Bidang Audit dan Pengawasan Ekstrenal

\begin{tabular}{|c|c|c|}
\hline \multicolumn{1}{|c|}{$50 \%$} & \\
\hline $\begin{array}{c}\text { Audit Eksternal Menjamin } \\
\text { Efektivitas dan Akuntabilitas } \\
\text { Pemerintah Daerah }\end{array}$ & $\begin{array}{c}\text { Adanya fungsi pengawasan yang } \\
\text { efektif terhadap manajemen } \\
\text { keuangan daerah }\end{array}$ & TOTAL \\
\hline
\end{tabular}

Sumber : data diolah (2014)

\section{KESIMPULAN DAN SARAN}

\section{Kesimpulan}

a. Proses perencanaan dan penganggaran di kabupaten Merauke pada hakekatnya sudah berjalan dengan baik, namun penetapan perundang-undangan perencanaan dan penganggarannya belum tepat waktu. Penentuan target 
anggaran sudah dilakukan dengan layak dan proses penyusunannya pun cukup realisitis dan dinilai baik, demikian juga sistem pemantauan dan evaluasi partisipasi yang komprehensif telah berjalan dengan cukup baik.

b. Pelaksanaan anggaran di kabupaten Merauke secara keseluruhan sudah berjalan dengan baik. Penerapan praktik-praktik manajemen kas yang efektif guna memastikan pengelolaan dana yang efisien dalam pelayanan sudah berjalan baik dengan sistem pemungutan dan penagihan yang efisien. Sistem akuntansi yang menjamin terlaksananya akuntansi yang tepat atas seluruh transaksi keuangan dan menghasilkan laporan keuangan eksternal dan internal juga sudah dapat diandalkan, wajar, dan tepat waktu. Namun Pengelolaan yang hati-hati atas pinjaman daerah, investasi daerah, serta kepemilikan dalam BUMD belum cukup baik pelaksanaannya. Demikian juga upaya peningkatan keefektifan pengelolaan aset daerah melalui perencanaan dan pengelolaan aset jangka panjang yang menjamin terciptanya layanan terbaik dalam mendukung kelancaran aktifitas pemerintahan belum dilakukan dengan baik di kabupaten Merauke.

c. Pengawasan dan Akuntabilitas yang dilakukan di Kabupaten merauke sudah berjalan dengan cukup baik walaupun SDM yang berkualifikasi jabatan fungsional auditor dan yang berlatar belakang akuntansi jumlahnya belum memadai. Temuan audit internal di kabupaten Merauke selalu segera ditindaklanjuti, namun untuk audit eksternal guna menjamin 
efektivitas dan akuntabilitas pemerintah daerah, belum optimal dilaksanakan di kabupaten Merauke.

\section{Saran}

a. Dalam upaya untuk meningkatkan pendapatan yang bersumber dari pajak dan retribusi melalui intensifikasi dan ektensifikasi pada sumber-sumber pajak dan retribusi daerah yang potensial, maka diperlukan beberapa kegiatan yaitu : (i) Kajian potensi dan pemetaan pajak dan retribusi di Kabupaten Merauke, (ii) penambahan sarana dan sumber daya manusia pemungutan pajak dan retribusi daerah, (iii) sosialisasi dan pemberian penyuluhan kepada masyarakat mengenai pajak dan retribusi daerah, (iv) peningkatan pengawasan terhadap pelaksanaan pemungutan pajak dan retribusi daerah.

b. Untuk itu diperlukan beberapa kebijakan pemerintah daerah yaitu: (i) melaksanakan penyusunan APBD yang tepat waktu, (ii) meningkatkan efektifitas belanja, dan (iii) meningkatkan integrasi antara perencanaan dengan penganggaran. Guna mendukung kebijakan-kebijakan tersebut diperlukan beberapa kegiatan antara lain: (i) pendampingan dalam penyusunan RKA-SKPD, pendampingan dalam penyusunan KUA-PPAS bagi TAPD, (iii) penguatan MKPP pada seluruh SKPD.

c. Dengan kondisi belanja seperti ini maka pemerintah daerah sepatutnya meningkatkan daya serap belanja dan belanja per kapita agar pelayanan pada masyarakat selalu dapat ditingkatkan setiap tahun. 
d. Oleh karena sektor pendidikan dan kesehatan sangat terkait erat secara langsung terhadap kesejahteraan masyarakat, maka pemerintah daerah perlu memiliki komitmen yang tinggi setiap tahunnya untuk mengalokasikan minimal belanja pendidikan dan kesehatan sebesar $20 \%$ sebagaimana yang di atur dalam undang-undang.

e. Untuk mendukung pencapaian tersebut maka diperlukan beberapa kegiatan yakni : (i) pendampingan penyusunan Renstra SKPD Dinas Pendidikan dan Kesehatan yang sesuai dengan peraturan, (ii) pendampingan penyusunan ASB (Analisis Standar Belanja) di Dinas Pendidikan dan kesehatan, (iii) pelatihan dan pendampingan penyusunan RKA/DPA pada unit organisasi yang lebih kecil.

f. Terkait dengan masih belum optimal pengelolaan keuangan di Kabupaten Merauke maka Pemerintah daerah perlu mengupayakan perbaikan dan peningkatan pemahaman pengelola keuangan daerah untuk beberapa aspek perencanaan dan pengelolaan keuangan. Untuk itu diperlukan kegiatan-kegiatan berupa pendampingan (i) penyusunan Renstra SKPD, penyusunan SPM, dan penyusunan ASB. Selain itu juga, pelatihan perencanaan penganganggaran, penatausahaan, pengelolaan aset, serta pendampingan dalam membantu pemerintah daerah membuat regulasi tentang pokok-pokok pengelolaan keuda, aset, dan akuntansi.

g. Berkaitan dengan SDM pengelolaan keuangan daerah yang masih kurang di daerah, maka perlu ada lembaga Ad Hoc berupa Pembentukan Klinik perencanaan dan keuangan 
daerah yang diharapkan dapat memberikan bantuan berupa : pendampingan penyusunan dokumen perencanaan, penganggaran, penatausahaan, akuntansi dan pelaporan.

\section{DAFTAR PUSTAKA}

Bagian Keuangan Setda Merauke. Anggaran Pendapatan dan Belanja Daerah Kabupaten Merauke Tahun 2007 sampai dengan 2011. Pemerintah Kabupaten Merauke, Merauke.

BAPPEDA Merauke. Rencana Definitif Dana Otonomi Khusus Kabupaten Merauke Tahun 2007-2011. Badan Perencanaan dan Pembangunan Daerah Kabupaten Merauke, Merauke.

BPS Merauke. Indeks Pembangunan Manusia Tahun 2014. Badan Pusat Statistik Kabupaten Merauke, Merauke.

. Merauke Dalam Angka Tahun 2011-2014. Badan Pusat Statistik Kabupaten Merauke, Merauke.

BPS Papua. 2010. Susenas Provinsi Papua 2010. Badan Pusat Statistik Provinsi Papua, Jayapura.

DISPENDA Merauke. 2014. Pendapatan Daerah Kabupaten Merauke Tahun 2014. Dinas Pendapatan Daerah Kabupaten Merauke, Merauke.

Juanda, B., et al. 2013. Evaluasi Regulasi Pengelolaan Keuangan Daerah Dan Pengaruhnya Terhadap Upaya Peningkatan Kualitas Belanja Daerah. Kementerian Keuangan RI, Jakarta.

Langoday, T. O. 2011. Survey Public Finance Management (PFM) Di Kabupaten Flores Timur Provinsi Nusa Tenggara Timur. Journal of Indonesian Applied Economics : Vol. 5 No. 2 Oktober 2011, p. 205-223.

Wordpress. 2012. Merauke Daerah Percontohan Penanganan HIVIAIDS. [http://kbrpapua.wordpress.com] 
Lampiran 1. Skor Dimensi Dalam Pengelolaan Keuangan Daerah Kabupaten Merauke

\begin{tabular}{|c|c|c|c|c|}
\hline Area & Outcomes & $\begin{array}{c}\text { Total } \\
\text { Achievable } \\
\text { Score }\end{array}$ & $\begin{array}{c}\text { Total } \\
\text { Achieved } \\
\text { Score }\end{array}$ & $\begin{array}{c}\text { Area } \\
\text { Grade } \\
(\%)\end{array}$ \\
\hline \multirow[t]{4}{*}{$\begin{array}{l}\text { BIDANG 1: } \\
\text { KERANGKA } \\
\text { PERATURAN } \\
\text { PERUNDANGAN } \\
\text { DAERAH }\end{array}$} & $\begin{array}{l}\text { Adanya Kerangka Peraturan } \\
\text { Peraturan Perundangan Daerah } \\
\text { yang komprehensif sebagaimana } \\
\text { diamanatkan oleh kerangka } \\
\text { hukum nasional mengenai } \\
\text { pengelolaan keuangan daerah }\end{array}$ & 15 & 4 & $27 \%$ \\
\hline & $\begin{array}{l}\text { Kerangka Peraturan } \\
\text { Perundangan Daerah Mengenai } \\
\text { Penegakan Hukum dan Struktur } \\
\text { Organisasi yang Efektif }\end{array}$ & 3 & 3 & $83 \%$ \\
\hline & $\begin{array}{l}\text { Kerangka Peraturan } \\
\text { Perundangan Daerah Mencakup } \\
\text { Ketentuan-Ketentuan untuk } \\
\text { Meningkatkan Transparansi dan } \\
\text { Partisipasi Masyarakat } \\
\end{array}$ & 3 & 0 & $0 \%$ \\
\hline & TOTAL & 21 & 6.5 & $31 \%$ \\
\hline \multirow{4}{*}{$\begin{array}{l}\text { BIDANG 2: } \\
\text { PERENCANAAN } \\
\text { DAN } \\
\text { PENGANGGARAN }\end{array}$} & $\begin{array}{l}\text { Tersusunnya perencanaan dan } \\
\text { penganggaran multi-tahun }\end{array}$ & 6 & 5 & $83 \%$ \\
\hline & $\begin{array}{l}\text { Target Anggaran yang Layak dan } \\
\text { Berdasarkan Proses Penyusunan } \\
\text { Anggaran yang Realistis }\end{array}$ & 5 & 3 & $60 \%$ \\
\hline & $\begin{array}{l}\text { Sistem Pemantauan dan Evaluasi } \\
\text { Partisipatif yang Komprehensif } \\
\text { dalam Proses Perencanaan dan } \\
\text { Penganggaran Telah Terbentuk }\end{array}$ & 5 & 2.55 & $51 \%$ \\
\hline & TOTAL & 16 & 10.55 & $66 \%$ \\
\hline \multirow[t]{5}{*}{$\begin{array}{l}\text { BIDANG 3: } \\
\text { PENGELOLAAN } \\
\text { KAS }\end{array}$} & $\begin{array}{l}\text { Kebijakan, Prosedur, dan } \\
\text { Pengendalian untuk Mendorong } \\
\text { Pengelolaan Kas yang Efisien } \\
\text { Telah Dibentuk }\end{array}$ & 11 & 4.5 & $41 \%$ \\
\hline & $\begin{array}{l}\text { Penerimaan Kas, Pembayaran } \\
\text { Kas, Serta Surplus Kas Temporer } \\
\text { Dikelola dan Dikendalikan Secara } \\
\text { Efisien }\end{array}$ & 7 & 4.5 & $64 \%$ \\
\hline & $\begin{array}{l}\text { Terdapat Sistem Penagihan dan } \\
\text { Pemungutan Pendapatan Daerah } \\
\text { yang Efisien }\end{array}$ & 7 & 7 & $100 \%$ \\
\hline & $\begin{array}{l}\text { Peningkatan dan Penanganan } \\
\text { Manajemen Pendapatan }\end{array}$ & 5 & 3 & $60 \%$ \\
\hline & TOTAL & 30 & 19 & $63 \%$ \\
\hline
\end{tabular}




\begin{tabular}{|c|c|c|c|c|}
\hline Area & Outcomes & $\begin{array}{c}\text { Total } \\
\text { Achievable } \\
\text { Score }\end{array}$ & $\begin{array}{c}\text { Total } \\
\text { Achieved } \\
\text { Score }\end{array}$ & $\begin{array}{c}\text { Area } \\
\text { Grade } \\
(\%)\end{array}$ \\
\hline \multirow[t]{2}{*}{$\begin{array}{l}\text { BIDANG 4: } \\
\text { PENGADAAN }\end{array}$} & $\begin{array}{l}\text { Meningkatkan efisiensi dalam } \\
\text { kegiatan pengadaan barang dan } \\
\text { jasa daerah yang menghasilkan } \\
\text { peningkatan kompetisi, } \\
\text { menyediakan peningkatan nilai } \\
\text { uang (penghematan) belanja } \\
\text { daerah, menciptakan } \\
\text { transparansi yang lebih baik, } \\
\text { serta menghasilkan akuntabilitas } \\
\text { yang lebih baik. }\end{array}$ & 16 & 10 & $63 \%$ \\
\hline & TOTAL & 16 & 10 & $63 \%$ \\
\hline \multirow[t]{5}{*}{$\begin{array}{l}\text { BIDANG 5: } \\
\text { AKUNTANSI DAN } \\
\text { PELAPORAN }\end{array}$} & $\begin{array}{l}\text { Adanya Kapasitas SDM dan } \\
\text { Kelembagaan yang Memadai } \\
\text { untuk Fungsi Akuntansi dan } \\
\text { Keuangan }\end{array}$ & 5 & 3 & $60 \%$ \\
\hline & $\begin{array}{l}\text { Sistem Informasi Akuntansi dan } \\
\text { Manajemen Sudah Terintegrasi }\end{array}$ & 4 & 2 & $50 \%$ \\
\hline & $\begin{array}{l}\text { Seluruh Transaksi dan Saldo } \\
\text { Keuangan Pemerintah Daerah } \\
\text { Dicatat Secara Akurat dan Tepat } \\
\text { Waktu }\end{array}$ & 5 & 4 & $80 \%$ \\
\hline & $\begin{array}{l}\text { Terdapat Laporan Keuangan dan } \\
\text { Informasi Manajemen Anggaran } \\
\text { yang Dapat Diandalkan }\end{array}$ & 5 & 3 & $60 \%$ \\
\hline & TOTAL & 19 & 12 & $63 \%$ \\
\hline \multirow[t]{4}{*}{$\begin{array}{l}\text { BIDANG 6: } \\
\text { PENGAWASAN } \\
\text { INTERN }\end{array}$} & $\begin{array}{l}\text { Bawasda Terorganisir dan } \\
\text { Diberdayakan untuk Beroperasi } \\
\text { dengan Efektif }\end{array}$ & 9 & 5 & $56 \%$ \\
\hline & $\begin{array}{l}\text { Standar dan Prosedur Audit } \\
\text { Internal yang Diaplikasikan Dapat } \\
\text { Diterima }\end{array}$ & 7 & 5.75 & $82 \%$ \\
\hline & $\begin{array}{l}\text { Temuan Audit Internal } \\
\text { Ditindaklanjuti dengan Segera }\end{array}$ & 2 & 2 & $100 \%$ \\
\hline & TOTAL & 18 & 12.75 & $71 \%$ \\
\hline \multirow[t]{3}{*}{$\begin{array}{l}\text { BIDANG 7: } \\
\text { HUTANG DAN } \\
\text { INVESTASI } \\
\text { PUBLIK }\end{array}$} & $\begin{array}{l}\text { Kebijakan, Prosedur, serta } \\
\text { Pengendalian dan Pinjaman } \\
\text { Investasi Daerah yang } \\
\text { Memperhitungkan Resiko Telah } \\
\text { Ditetapkan dan Dilaksanakan }\end{array}$ & 5 & 1 & $20 \%$ \\
\hline & $\begin{array}{l}\text { Kebijakan, Prosedur dan } \\
\text { Pengelolaan Penerimaan Hibah } \\
\text { telah ditetapkan dan dilaksanakan }\end{array}$ & 5 & 1 & $20 \%$ \\
\hline & TOTAL & 10 & 2 & $20 \%$ \\
\hline
\end{tabular}




\begin{tabular}{|c|c|c|c|c|}
\hline Area & Outcomes & $\begin{array}{l}\text { Total } \\
\text { Achievable } \\
\text { Score }\end{array}$ & $\begin{array}{c}\text { Total } \\
\text { Achieved } \\
\text { Score }\end{array}$ & $\begin{array}{c}\text { Area } \\
\text { Grade } \\
(\%)\end{array}$ \\
\hline \multirow[t]{4}{*}{$\begin{array}{l}\text { BIDANG 8: } \\
\text { PENGELOLAAN } \\
\text { ASET }\end{array}$} & $\begin{array}{l}\text { Terdapat kebijakan yang } \\
\text { mengatur penggunaan dan } \\
\text { pemanfaatan aset daerah yang } \\
\text { mendukung tertib pengelolaan } \\
\text { aset daerah }\end{array}$ & 7 & 2 & $29 \%$ \\
\hline & $\begin{array}{l}\text { Kebijakan dan prosedur } \\
\text { pemeliharaan asset dilakukan dan } \\
\text { terintegrasi dengan proses } \\
\text { perencanaan daerah untuk } \\
\text { memastikan kondisi aset selalu } \\
\text { siap digunakan }\end{array}$ & 4 & 2 & $50 \%$ \\
\hline & $\begin{array}{l}\text { Terdapat kebijakan, sistem dan } \\
\text { prosedur pencatatan, perolehan, } \\
\text { penilaian, pemindahtangan dan } \\
\text { penghapusan dan pelaporan } \\
\text { barang daerah yang efektif }\end{array}$ & 9 & 3 & $33 \%$ \\
\hline & TOTAL & 20 & 7 & $35 \%$ \\
\hline \multirow{3}{*}{$\begin{array}{l}\text { BIDANG 9: AUDIT } \\
\text { DAN } \\
\text { PENGAWASAN } \\
\text { EKSTERNAL }\end{array}$} & $\begin{array}{l}\text { Audit Eksternal Menjamin } \\
\text { Efektivitas dan Akuntabilitas } \\
\text { Pemerintah Daerah }\end{array}$ & 6 & 1 & $17 \%$ \\
\hline & $\begin{array}{l}\text { Adanya fungsi pengawasan yang } \\
\text { efektif terhadap manajemen } \\
\text { keuangan daerah }\end{array}$ & 4 & 2 & $50 \%$ \\
\hline & TOTAL & 10 & 3 & $30 \%$ \\
\hline \multicolumn{2}{|c|}{ Total Statements } & 160 & 82.8 & $52 \%$ \\
\hline
\end{tabular}

Sumber : data diolah (2014) 